\title{
A NOTE ON THE DISTRIBUTION AND HOSTS OF IXODES PILOSUS HOWARDI, Neum.
}

By C. W. Howard, Pretoria.

(Read June 17, 1908.)

In the preceding article Professor Neumann has described a new tick from the Transvaal. Some notes on its distribution and hosts may be of interest to those making a study of this group.

The first specimens were sent to me by Dr. Copland, the District Surgeon at Leydsdorp; at about the same time Dr. Theiler brought specimens from Durban. It was from these specimens that Professor Neumann described the varieiy. Since that time I have taken specimens from the following places in the Transvaal: Lenokana Location, Marico District; Pilansberg Mountains, Rustenburg District; Pienaars River, Pretoria District; Ivy Mine, Moodies, Barberton District; and the Zoutpansberg Mountains in the Zoutpansberg District.

Mr. Lounsbury, in one of his reports, states that I. pilosus is only found in Cape Colony in places which are very humid, such as kloofs containing a stream of running water, or in the vicinity of vleis. Apparently I. pilosus howardi is not limited in its distribution to these conditions. None of the above-mentioned places can be considered as humid ; on the contrary, the majority of them are more or less dry, unless we can consider Durban as humid, and some of the localities-such as Leydsdorp and the Zoutpansberg Mountains-are very arid.

Most of the localities are in the low and bush veld, but those places on the high veld (above 4,000 feet), where the tick is common, are in those parts which are covered with bush, and the tick is apparently lacking in the high grass veld.

The principal host is the dog, but at the Ivy Mine, Moodies, Barberton, a few specimens were found on a cat, and a few on a hedgehog at Pienaars River. 


\section{$2 \mathrm{BHL}$ Biodiversity Heritage Library}

Howard, C W . 1909. "A NOTE ON THE DISTRIBUTION AND HOSTS OF IXODES PILOSUS HOWARDI, Neum." Transactions of the Royal Society of South Africa 1, 126-126. https://doi.org/10.1080/00359190909520031.

View This Item Online: https://www.biodiversitylibrary.org/item/181696

DOI: https://doi.org/10.1080/00359190909520031

Permalink: https://www.biodiversitylibrary.org/partpdf/175457

\section{Holding Institution}

Smithsonian Libraries

\section{Sponsored by}

Biodiversity Heritage Library

\section{Copyright \& Reuse}

Copyright Status: Not in copyright. The BHL knows of no copyright restrictions on this item.

This document was created from content at the Biodiversity Heritage Library, the world's largest open access digital library for biodiversity literature and archives. Visit BHL at https://www.biodiversitylibrary.org. 